\title{
Teachers' Formation in Higher Education: Some Aspects under the Light of Education-Work Relations
}

\author{
Rosane Michelli de Castroㅁ, Vandeí Pinto da Silva² \\ ${ }^{1}$ Department of Didactics, Program of Postgraduate on Education, Faculty of Philosophy and Sciences, \\ University Estadual Paulista "Julio de Mesquita Filho" — UNESP/Marília, São Paulo, Brazil \\ ${ }^{2}$ Department of Didactics, Faculty of Philosophy and Sciences, University Estadual Paulista "Julio de Mesquita \\ Filho"-UNESP/Marília, São Paulo, Brazil \\ Email: rosanemichelli@marilia.unesp.br, vandeips@uol.com.br
}

Received 3 August 2014; revised 2 September 2014; accepted 14 September 2014

Copyright (C) 2014 by authors and Scientific Research Publishing Inc.

This work is licensed under the Creative Commons Attribution International License (CC BY). http://creativecommons.org/licenses/by/4.0/

(c) (i) Open Access

\section{Abstract}

This text is mainly aimed to address essential aspects of teacher formation in the light of education-work relations in the higher education, from our systematic experience in higher education teaching, particularly teaching and research in the field of Didactics discipline. This formulation is justified considering our concern in seeking to situate this discussion in the context of bringing together knowledge areas and the field of teaching knowledge. Still, our choice to develop such an approach in the light of work-education relationship is due to the belief about the possibilities of seeking to overcome the requirements imposed by capitalism to our educational system, within the possible contradictions of these relationships. In this context the teachers' formation in higher education gains social and strategic importance, taking on the task of forming individuals of "action-reflection-action" in a society established historically based on the social relations which settle in the light of capital's multiple determinations. It appears that, in this sense, the major confrontations have been given within the discussions about what to prioritize or combine in the list of criteria and content for teacher's formation. In Didactic, we seek to emphasize discussions that we consider with a philosophical background, referring to the orientation of teaching practice in knowledge of contemporary ideological struggle; socio-historical, referring to the possibility of formation of disciplines, among them Didactic, and curriculums and references to support its guidance in the process of teacher's formation. This context of discussion is based on the concrete teaching practice with a view to transformation and to search for new syntheses in terms of knowledge and in terms of historical reality. Then therefore, our methodological approach grounded in the dimensions of the same unit: historical materialism as posture, method and as praxis. 


\section{Keywords}

\section{College Education, Teacher Formation, Historical Materialism}

\section{Introduction}

In this paper, we aimed to approach fundamentally essential aspects of Didactic and teacher formation in the light of higher education-work relations in higher education, from our systematic experience in higher education teaching, particularly teaching and research in the field and discipline of Didactic.

This approach is due to the belief about the possibilities of seeking to overcome the requirements imposed by capitalism to our educational system, within the possible contradictions of these relationships.

In this context the teachers' formation in higher education gains social and strategic importance, taking on the task of forming individuals of "action-reflection-action” in a society established historically based on the social relations which settle in the light of capital's multiple determinations. It appears that, in this sense, the major confrontations have been given within the discussions about what to prioritize or combine in the list of criteria and content for the teacher's formation. What skills or areas of knowledge would be the contribution to build the set of knowledge for teachers who work in higher education?

In the Didactic, specifically in the Didactic disciplines that integrate the Pedagogy Course curriculum at the University in which its researchers are teachers, we seek to emphasize discussions that we consider with a philosophical background, referring to the orientation of the teaching practice in knowledge of contemporary ideological struggle; socio-historical, referring to the possibility of formation of the disciplines, among them Didactic, and curriculums and references to support its guidance in the process of teacher's formation. By the way, in the first topic of this paper we discuss aspects that, especially in the Didactic inside a course aimed at teacher's formation in the college level, we believe that are essential and that relate to future teachers' mobilizing for action-reflection-action about educational phenomena that occur in society and particularly in education seeking with rigor and objectivity their multiple determinations within capitalist relations, which we believe can only be possible in the light of a world view, a method and a praxis that constitute unit historical materialism and its dialectic.

In this sense, in the second topic we highlight a key concern regarding our students in initial teacher formation which is the one done in school. And finally, we favor dialogue with the theories of István Mészáros in "Education beyond capital” (2005), which, through philosophical and historical-sociological perspective, has grounded our discourse and our initial work in the disciplines of Didactic. Certainly it is one more opportunity to address the issue of the Didactic in Teaching Superior. But, we present aspects of our experience, as mentioned.

\section{Historical Materialism: Rigor and Objectivity for Teaching in College Education}

As stated, our choice for developing essential aspects of teacher formation in the light of higher education-work relations in the higher education, activity to which we have dedicated ourselves within the disciplines of Didactic inside a Pedagogy course, is due to the belief of the possibilities of seeking to overcome the requirements imposed by capitalism to our educational system, within the possible contradictions in these relationships.

Based on the dialectical method of historical materialism, whose foundations were laid by Marx and Engels, it is required of those who assume to search for radical seizure (root) of a phenomenon in its essence, further than it is immediately noticeable, in an effort to unveil the laws that produced this phenomenon, with posture and conception of the world.

In this sense, adopting the framework of historical materialism implies working rigorously with historically constructed categories, and from which, the method acquires concreteness, as totality, contradiction, mediation and alienation.

It means that, when we adopt historical materialism as posture and method, the researcher brings to the reality plane a dialectical grounded in those categories that are guided in the human way of social production of existence. Thus, as a method of analysis, the dialectics of historical materialism binds to a conception of reality, the world and life in its entirety. "It constitutes, therefore, a sort of mediation in the grasp, reveal and expose the structure, development and transformation of social phenomena process” (Penitente, Castro, \& Garrossino, 2007: 
p. 214).

However, the explanation of the whole process of apprehension, exposure of structuring of a phenomenon in its mediations, in other words, knowledge in historical materialism is realized in and through praxis that expresses the indissoluble unity of theory and action.

Then has a cycle in which knowledge of a particular fact, the previous phenomenon, apparently, is overcome and replaced according to a new interpretation in the light of categories that reveal the laws of this phenomenon and allow new actions, that are superior than the previous one.

Thus, as stated Frigotto (2006) when it adopts its dialectical and historical materialism as a world view, method and practice, the researcher does not feel apprehended in a "straitjacket" by theory, or the analysis' categories, or also taken by a random reference. There is a historic building on the real phenomenon, fed up with essence and theoretical foundation to reset the cycle of praxis by man in all production processes of life, therefore distanced from the pseudo-caused conditions imposed by the capitalist's relations in their institutions generated within our society.

The proposal is, according to Gramsci (1978 apud Frigotto, 2006: p. 77), breaking with the alienating logic imposed on those institutions of our social system and, in particular, in our public school dedicated to the educator's formation, and seek to promote a thought of review and investigation based on different conceptions of reality gestated in the cultural, historical, therefore concrete world.

"By the very conception of the world, we always belong to a particular group, specifically to all social elements which share the same way of thinking. We are conformists of some conformism, we are always manmass or collective man. The problem is this: what is the historical type of conformism and the mass man to which we belong? [...] The top of critical elaboration is the consciousness of what we really are, that is a 'know thyself' as a historical product developed until today, that left in you an infinity of traces received for their benefit in inventory. Should do initially, this inventory” (Gramsci, 1978 apud Frigotto, 2006: p. 78).

\section{The Teacher's Formation in School: A Central Concern}

Faced with the conception of the world, method and praxis assumed by us in the Didactic inside a formation course for teachers at the college level, the search is to prepare future teachers for the pursuit of knowledge of the school, from which it is possible to think in curricula and references for the construction of schools and teacher education itself.

It means that we are forwarding our future teachers to form up and act in the concrete world, and the relationships and mediations that occur in the workplace of teachers and students: in school.

According to Imbernón (2004: p. 80) in "teaching and vocational training-train yourself to change and uncertainty", a formation focused on school "[...] involves all the strategies employed jointly by trainers and teachers to driving formation programs so that they meet the defined needs of the school and to raise the quality of teaching and learning in the classroom and school room”. It must be understood, therefore, that the school should be turned into a priority place for education, before other actions or formation institutions.

To Imbernón (2004: p. 80) "it is not only a training as a collection of techniques and procedures, but it has an ideological load, values, attitudes and beliefs". It is important to remember that this is not a simple change "[...] of focus to redefine content, strategies, the protagonists and the purposes of formation".

Therefore, aims to develop a collaborative and participatory culture, allowing:

- Processes of "action-reflexion-action";

- Change of cultural reality;

- New values: to propose interdependence, professional openness, communication, educational act of making a public act, collaboration, autonomy, self-regulation and collaborative critique;

- Collaborate not as a management strategy, but as a work philosophy;

- Processes of participation, involvement, ownership and belonging;

- Respect and recognition of the power and capacity of teachers;

- Search of power and capacity by teachers;

- Reset and expansion of school management.

In pursuit of this culture, it can be identified four phases, according to Imbernón (2004):

- Preparation includes the beginning of the experiment and trading on the participation and control; 
- Review: includes planning, instrumentation, mobilization of means, obtainment of information, conclusions, among others;

- Development: to plan and to implement innovation;

- Institutionalization or maintenance of innovation.

The phases above can be associated with central generation process of a school's culture, known among educators as Political Pedagogical Project.

It matters, in this process, working centrally with all the subjects of the "school community" the idea that the journey of building the school, through a project, lies on the school itself and happens by themselves, driven by needs and own utopias, whose satisfaction is dependent to means and methods for the community itself. And all of this has to be discursively materialized in a systematic way and planned in a project format, so that nothing gets lost in route.

It follows that, a first definition worked on with students in teacher's formation, it is one of the Pedagogical or School Project, understood according to Vasconcelos (1999: p. 169) as systematization, never definitive, of a participatory planning process that improves and manifests itself in the walk that clearly defines the type of educational activity that wants to accomplish. Yet, the Pedagogical School Project can be defined as "[...] a theoretical and methodological tool for intervention and change of reality" (Vasconcelos, 1999: p. 169), whose effectiveness is due to the collective participation of the subjects of the school community in the construction of this instrument which is ultimately the result of the construction of knowledge about the school itself.

A first involvement exercise proposed is the contextualization of school and pedagogical practices observable in it. Then it's possible to fit the questions and reflections about:

- everyday of school, and schools nowadays;

- the difficulties and possibilities of overcoming these difficulties;

- and the personal role of each one in the future to overcome the difficulties in work.

This step completed, it can fits the proposition of reflection about the school's importance and each one's participation as educators by the light of education-work relations, centrally after the 1990s permeated the discourse of decentralization of education, in response to the legitimacy State's crisis, from which one must think and value the school as a place of organization where workers must construct their identity, and thus should work more with the plurality than with equality, with more significance than the specific content, having a lot of clarity on the issue of culture and local government in its relations with the global, and in the limit this new school will have to bring all those involved to reflect and act in favor of a school able to think in organizing situations, activities and enabling environments for the teaching-learning process. Given this scenario, it is impose the need for:

- an education project that reflects the views of the school about the education, the human person to be formed, the guiding values of society;

- a project management embodying these ideas, creating conditions so that the pedagogical can happen daily at school.

Under this perspective, the project of a school can only be idealized if it s fabricated on the school community's collective: focusing on the student; considering the context of school integration; encouraging the creation of study and reflection and interfering in the general articulation of curriculum and, finally, requiring teachers and other professionals working in school to have knowledge and to know how to do.

\section{Mészáros: A Theoretical Referential}

The theories of Mészáros (2005) "Education beyond capital” which, through philosophical and historical-sociological perspective, has grounded our discourse and our initial work in the Didactic disciplines, is a result of our political commitment to a school and an education with quality and emancipatory for all, greatly to our students in teacher formation.

According to this, we seek to think about teacher formation that occurs in schools, with teachers who work in their classrooms or administrative functions, and the possible links with the struggle for a human-centered education and not the logic of capital.

Mészáros (2005) shows that to think of education with that point of view, it is necessary to think of society having as parameter the human being, which "[...] requires overcoming this dehumanizing logic of capital, which has on individualism, on profit and on competition its foundations” (Mészáros, 2005: p. 9). Also he states 
that it is necessary to understand that educating means, as Gramsci, “[...] an end to the separation between Homo faber and Homo sapiens; it is to rescue the structuring meaning of education and its relationship with work, their creative and emancipatory possibilities [...], task that goes far beyond the classrooms, schools, offices and academic forums” (Mészáros, 2005: p. 9).

In Mészáros (2005) there are proposals of reflections on the role of education in building another possible world; the possibilities of building an education whose main reference is the human being and which makes the necessary political, economic, cultural and social changes (p. 10).

Mészáros (2005) calls attention to the fact that "[...] educational exclusion does not occur mainly over the issue of access to school, but inside of it, through formal education institutions” (Mészáros, 2005: p. 11). Thus, he states that "what it is at stake is not only the political change in the educational process-that practices and aggravates the social apartheid-, but the reproduction of the structure of values that helps perpetuate a world view based on mercantile society” (Mészáros, 2005: pp. 11-12).

Mészáros (2005) argues that education should always be continuous, permanent, or it is not education. He defends the existence of educational practices that enable educators and students to work the necessary changes to build a society in which capital does no longer explore workers in their work and leisure time, because he states that the ruling classes require an education for alienating work in order to keep the man dominated. However, he points out that our struggle must be for a liberating education that would has as function to make the worker a political agent, who thinks, acts, and uses the word as a weapon to change the world. According to him, an education beyond capital must go hand in hand with the struggle for a radical transformation of the current hegemonic political and economic model (Mészáros, 2005: p. 12).

Thus what we want to reflect with our students and future teachers are the possibilities of seeking, through education, to identify the contradictions of capital and the social relations engendered by it, for only then we could go beyond the limits of performance required by the dehumanizing logic. For, as stated by Mészáros (2005: p. 12): "therefore, to limit a radical educational change to the self-seeking corrective margins of capital means abandoning at once, consciously or not, the purpose of a qualitative transformation".

\section{By Way of Conclusion}

Considering that the proposed plan discussions in this text is based on the actual teaching practice with a view to transformation and search for new syntheses in terms of knowledge and in terms of historical reality, we believe that our methodological option to develop it is coherently based on the dimensions of historical materialism as a worldview, as a method, and as praxis. Certainly it is one more opportunity to address the issue of the Didactic in Teaching Superior. But, we present aspects of our experience, as mentioned.

Here, then, it is where we highlight all the rigor and objectivity of Didactics in teacher education at the college level: never isolate the facts involved to "dissect" them in laboratories, but rather constantly situating those facts in the context that generates and explains them. Another objective is to analyze the potential of their practices to promote real equal opportunities for all sectors of society, from which we believe in the importance of teacher formation in schools.

Returning to Mészáros’ formulations (2005: pp. 52-53.):

"[...] wherever it is in relation to the 'maintenance', or it is in relation to 'change', it is a particular conception of the world, and the key issue is the need to modify, in a lasting way, the way of historically prevailing internalization. Breaking the logic of capital in education is absolutely inconceivable without it. And more importantly, this relationship can and should also be expressed in a concrete form. For through a radical change in the now oppressive internalization way, that maintains the dominant conception of the world, the rule of capital can and will be broken”.

And this is the task that we have leaned in the field of investigations and Didactic disciplines: seeking to highlight the possibilities that educators can build to change the mode of internalization of a world view "historically prevalent" and that should be expressed in a concrete form.

Reflecting on everything that involves school and educational practices, we paid attention that the processes of idealization, development and evaluation can and should be appropriate for male and female teachers as a place and time for the beginning of change processes about the conception of world, of man, of education, of school; in short, all the elements that involve the formation of man, especially through systematic knowledge, 
because learning, as Paracelsus says, occurs throughout life.

And reflect on new concepts mean, according to Mészáros (2005: p. 59), think them in exchange with "our own life", which means abdicate thinking them not only from the so-called great narratives that perpetuate the system capitalist, but primarily from petits récits, where you can extract the possibilities of individuals' disalienation (Mészáros, 2005: p. 63).

That is why the challenge to be faced by each subject inside a school, and life itself, is unparalleled in history; therefore, there are neither ready recipes nor a specific field of pedagogical prescriptions as it has been made erroneous and historically references to Didactics.

\section{References}

Frigotto, G. (2006). O enfoque da dialética materialista histórica na pesquisa educacional. In I. Fazenda (Org.), Metodologia da pesquisa educacional (10th ed., pp. 69-90). São Paulo: Cortez.

Imbernón, F. (2004). Formação docente e profissional-formar-se para a mudança e a incerteza (4th ed.). São Paulo: Cortez.

Mészáros, I. (2005). A educação para além do capital. Trad. de Isa Tavares. São Paulo: Boitempo.

Penitente, L. A. A., Castro, R. M., \& Garrossino, S. R. B. (2007). Contribuições do método histórico dialético na pesquisa em educação. In M. Del Roio (Org.), Trabalho, política e cultura em Gramsci: os 70 anos da morte de Gramsci (pp. 213-216). Marília: Oficina Universitária Unesp.

Vasconcelos, C. S. (1999). Planejamento: projeto de ensino-aprendizagem e projeto político-pedagógico (5th ed.). São Paulo: Libertad. 
Scientific Research Publishing (SCIRP) is one of the largest Open Access journal publishers. It is currently publishing more than 200 open access, online, peer-reviewed journals covering a wide range of academic disciplines. SCIRP serves the worldwide academic communities and contributes to the progress and application of science with its publication.

Other selected journals from SCIRP are listed as below. Submit your manuscript to us via either submit@scirp.org or Online Submission Portal.
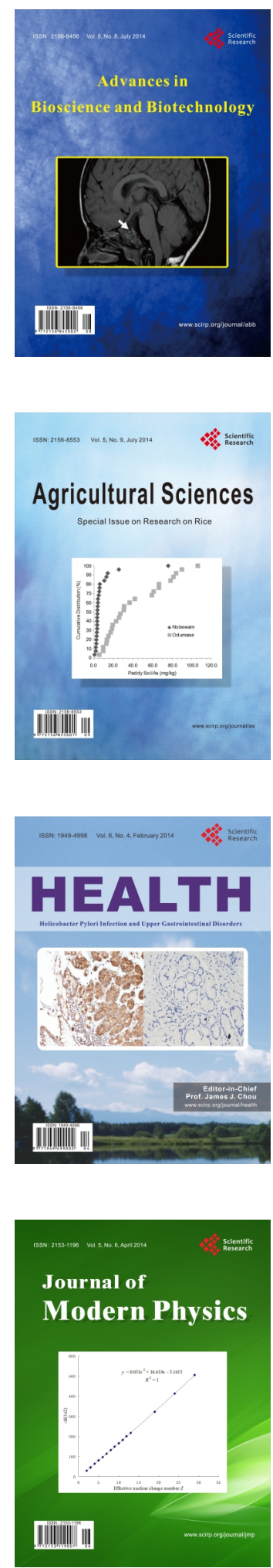
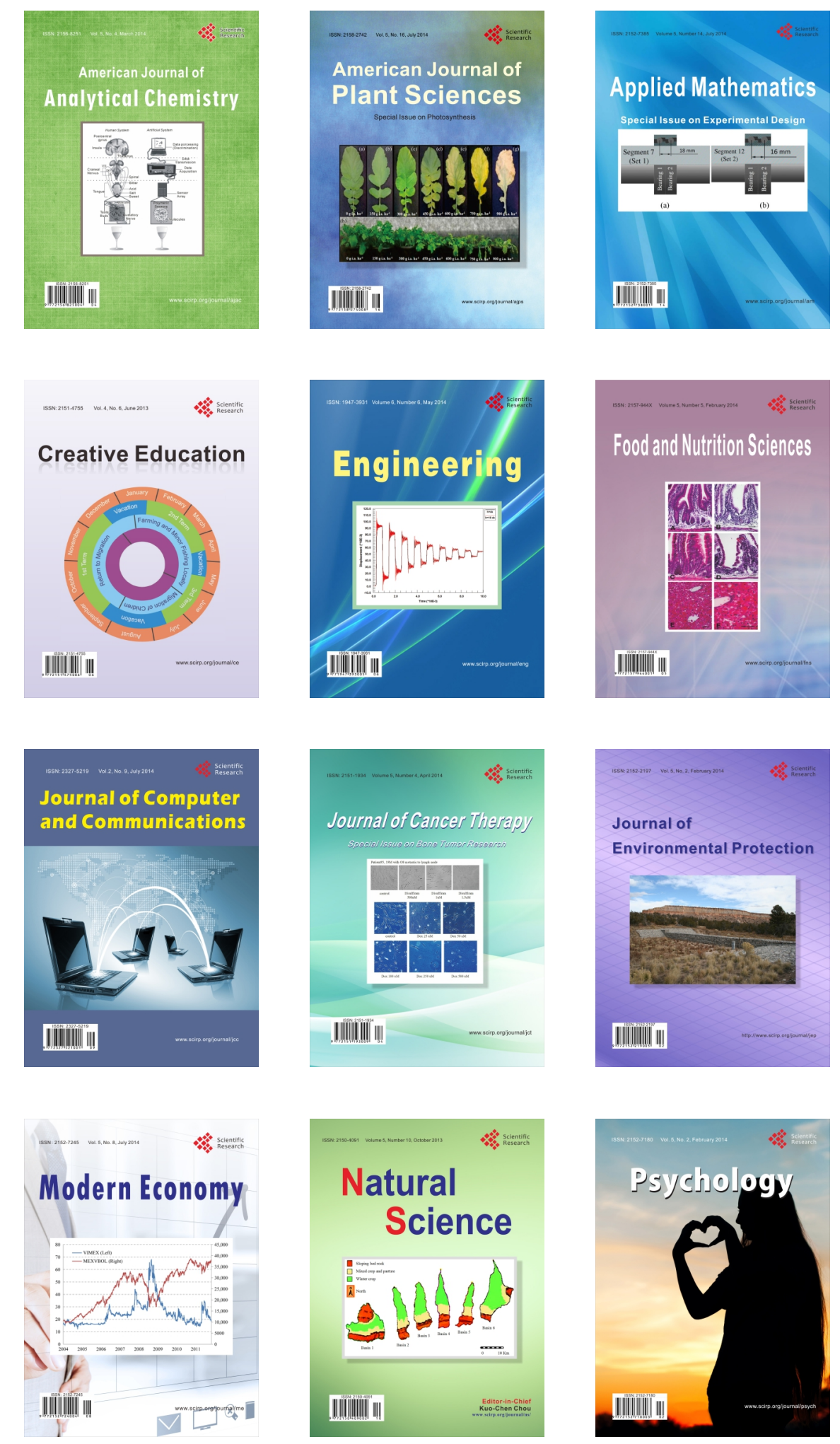